\title{
Conceptualising the Biblical View of Curse (Gen. 9:25-27) as a Metaphor for Natural Resource Curse in Zimbabwe: An Indigenous Knowledge Systems Perspective $^{1}$
}

\author{
Temba T. RugwiJi (UNiversity OF Pretoria)
}

\begin{abstract}
The African continent in general, and Zimbabwe in particular, continue to endure the acrimony of "natural resource curse" in spite of an abundance of natural resources. Africa consumes what it does not produce, and produces what it does not consume. The following three contestations constitute the milieu underpinning the present study: (1) the biblical text presents the entire human race as cursed through Adam (Gen. 3:17), (2) that Africans are cursed because they are portrayed as the descendants of Ham's son, Canaan, who was cursed by his grandparent, Noah (Gen. 9:25-27), and (3) biblical commentators continue to argue for the presence of an African in the biblical context; and Cush, Ham's eldest son, is perceived as "dark-skinned". In view of the above views, this study argues that a literal reading and interpretation of the Bible presents humans (especially Africans) as cursed. This discourse, therefore, interrogates the biblical concept of curse as a metaphor for curse in Zimbabwe. This argument is raised at the backdrop of Zimbabwe's wealth in natural resources such as land, gold, copper, platinum, nickel, iron, emeralds, and diamonds, among others. In addition, "chituko"/"ngozi" (avenging spirit) among the Shona people of Zimbabwe is also considered as a curse for uncompensated offences.
\end{abstract}

Keywords: Africa, Zimbabwe, curse, natural resource curse, chituko/ngozi, indigenous knowledge systems.

* Submitted: 28/12/2017; peer-reviewed: 25/04/2018; accepted: 02/05/2018. Temba T. Rugwiji, "Conceptualizing the Biblical View of Curse (Gen. 9:25-27) as a Metaphor for Natural Resource Curse in Zimbabwe: An Indigenous Knowledge Systems Perspective", OTE 31 no. 2 (2018): 363-388. DOI: https://doi.org/10.17159/23123621/2018/v31n2a6.

This article is a reworked version of a paper presented at the SBL Conference in Boston (USA), 18-21 Nov. 2017. 


\section{A INTRODUCTION}

This article uses two approaches: (1) a narrative inquiry research, and (2) hermeneutics of appropriation, in an attempt to engage in a critical dialogue the concept of curse in the biblical text as a metaphor for natural resource curse in Africa in general and Zimbabwe in particular. ${ }^{2}$ The study seeks to problematize the metaphor of curse in the biblical text, focusing on the narrative of Noah cursing his grandson, Canaan, Ham's son (Gen. 9:25-27). The study attempts to respond to the following three questions: (1) Are black people the descendants of Ham's son, Canaan, whom Noah cursed? (2) Are Africans cursed because they are the descendants of the biblical Cushites? And (3) Is natural resource curse in Africa a consequence of a curse from the Bible? The article explores unresolved questions of political and socio-economic crises that are devastatingly prevalent in the African continent. These crises tend to provoke the concept of a natural resource curse among Africans. Because the Bible plays a key role in the ethical and religious lives of African communities, the metaphor of curse cannot be ignored.

The biblical concept of curse is explored from an indigenous knowledge systems (IKS) perspective. ${ }^{3}$ The concept is appropriated in the broader African context, because it is an attempt to draw similarities and divergences between ancient Israel as depicted in the biblical text and the postcolonial African situation. The concept of curse is particularly appropriate in a Zimbabwean context since chituko/ngozi among the Shona people is regarded in a context in which one could be cursed for striking parents, swearing at elderly people, stealing livestock, and/or for murder. The consequences of chituko include "hungomwa" (childlessness), "hurovha" (joblessness), "kurwara-rwara" (persistent sickness), "kutanda botso" (mental disorder) and "ndufu" (deaths), among others. In addition, IKS is challenged and reoriented to focus on the broader spectrum of human life, with the aim of producing scholarly research results. It is further argued that "protest writing" is not only counterproductive, but also retrogressive.

2 A metaphor is a simile or an allegory. In this investigation, a curse metaphor drawn from the biblical text is employed in order to illustrate that a literal reading and interpretation of biblical narratives tends to deliberately present humans as cursed. Particular attention is paid on Africa in which poverty is prevalent in a continent which abounds in natural resources. If the Bible is largely believed to be the source of information about creation, the fall and the resultant curse of sinful humans, one is faced with a complexity of explaining why humans (especially Africans) suffer while having abundant natural resources at their disposal. The imagery of "natural resource curse" derives from the interpretation of the biblical text as explained above.

3 John Briggs, "The Use of Indigenous Knowledge in Development: Problems and Challenges," Progress in Development Studies 5/2 (2005): 99-114. 


\section{B STATEMENT OF THE PROBLEM}

Firstly, the biblical text infers that the human race was cursed for the sin/s that Adam committed (Gen. 3:17). Canaan was Ham's youngest son. Noah cursed his grandson, Canaan, because Ham, Noah's son, had seen the nakedness of his father (Gen. 9:20-27). In addition to that, Ham's other son, Cush, is portrayed as "dark-skinned"4. Presently, this submission is the first of its kind from a typical and indigenous African. I am unaware of any other literature in addition to the Bible which attempts to shed some light on the creation of the human race, particularly on the curse concept among Africans. In view of the above observation, this study interrogates the Bible as well as biblical commentators' interpretation of the curse concept. Secondly, the scarcity of scholarly contributions on the concept of curse in Zimbabwe from an Old Testament (OT)/theological perspective makes this study salient. I concur with Norman R. Whybray who writes that: "The dark side of God is a subject that has received astonishing little attention from OT scholars ..." Nonetheless, African biblical scholars $^{6}$ who argue for the presence of Africans in the Bible do not make references to "curse narratives"7 as depicted in the biblical text. Relevant contributions by African biblical scholars are interrogated in the present discourse. Thirdly, "protest writing" ${ }^{8}$ has continued to dominate various platforms such as the African biblical hermeneutics' section at SBL annual conferences. Such contributions also dominate the majority of African journals. At the same time, colonialism is constantly blamed for poverty and socioeconomic crises postcolonial Africa continues to experience. ${ }^{9}$ From an IKS perspective, it is argued in this article that Africa must mature from "pleading for sympathy" $"$. Similarly, African scholarship should focus more on concrete and pertinent issues such as production of knowledge technology (because

4 Jennifer L. Hochschild, "The Skin Colour Paradox and the American Racial Order," Social Forces 86/2 (2007): 1-28.

5 Norman R. Whybray, "Shall not the judge of all the earth do what is just? God's oppression of the innocent in the Old Testament," in Shall Not the Judge of All the Earth Do what is Right? Studies on the Nature of God in Tribute to James L. Crenshaw (ed. David Penchansky and Paul L. Redditt, Winona Lake: Eisenbrauns, 2000), 1-19.

6 See also Justin S. Upkong, "Rereading the Bible with African eyes," JTSA 91 (1995): 314

7 Albert I. Baumgarten, "Myth and Midrash: Genesis 9:20-29," in Christianity, Judaism, and Other Greco-Roman Cults: Studies for Morton Smith at Sixty (ed. Jacob Neusner et al.; Leiden: Brill, 1975), 55-71.

8 Rob Gaylard, "Writing Black: The South African Short Story by Black Writers" (PhD Thesis, University of Stellenbosch, 2008), 19.

9 For example, see Temba T. Rugwiji, "Towards the Quest for Transforming Old Testament Scholarship: The Impact of Political and Socioeconomic Crises on Scholarship in Zimbabwe," OTE 27/3 (2014):1009-1034.

10 This pleading for sympathy in my view, is on its own a dependency syndrome which "refuses" to detach itself from the former colonial master. 
technology embodies knowledge ${ }^{11}$ ) towards "weaning" the continent from foreign aid and the dependency syndrome. This discourse has also benefited from Bissell's contribution which explored "coloniality nostalgia among twenty-first century Africans". ${ }^{12}$ In this study, the notion of natural resource curse is explored as an impediment to Africa's socio-economic development.

\section{METHODOLOGY}

As noted above, two critical methods are used: (1) a narrative inquiry research method and (2) hermeneutics of appropriation. Clandinin and Connelly maintain that narrative inquiry is an umbrella term that captures personal and human dimensions of experience over time, and takes account of the relationship between individual experience and cultural context. ${ }^{13}$ Etherington concurs that narrative inquiry is a means by which one can systematically gather, analyse, and represent people's stories as told by them, which challenges traditional and modernist views of truth, reality, knowledge and personhood. ${ }^{14}$ Desk research/secondary data constitutes the milieu of the data pool in which secondary sources such as book chapters, journal articles, and internet sources have played a pivotal role in developing the present argument. ${ }^{15}$ According to Rugwiji, hermeneutics of appropriation concerns humans and their worldviews. ${ }^{16}$ Hermeneutics of appropriation is not concerned as much with the context itself; rather, it focuses on themes in the biblical text that can be appropriated in a contemporary situation. Natural resource curse and suffering among Africans are critical themes that influenced the present discourse. However, curse narratives from the ancient near Eastern (ANE) world and ancient Israel are brought into a dialogue, because the author is familiar with studies about ANE cultures.

\section{THE CONCEPT OF CURSE IN ANCIENT NEAR EAST}

Jan Assmann maintains that curses aim at total destruction and annihilation. ${ }^{17}$ They do not know any measure and limitation in drawing on the imagination of

11 Dennis R. Herschbach, "Knowledge as Technology: Implications for Instruction," Journal of Technology Education 7/1 (1995): 31.

12 William C. Bissell, "Engaging Colonial Nostalgia," Cultural Anthropology 20/2 (2014): 215-248.

13 Jean D. Clandinin and Michael F. Connelly, Narrative inquiry: Experience and Story in Qualitative Research (San Francisco: Jossey-Bass, 2000).

14 Kim Etherington, Narrative Approaches to Working with Adult Male Survivors of Childhood Sexual Abuse (London: Jessica Kingsley, 2000).

15 Melissa P. Johnston, "Secondary Data Analysis: A Method of which the Time Has Come," Qualitative and Quantitative Methods in Libraries 3 (2014): 619-626.

16 Temba Rugwiji, “Appropriating Judean postexilic Literature in a Postcolonial Discourse: A Case for Zimbabwe" (PhD thesis, University of South Africa, 2013), 6.

17 Jan Assmann, "Inscriptional Violence and the Art of Cursing: A Study of Performative Writing," Stanford Literature Review 8 (1992): 53. 
destruction. ${ }^{18}$ Furthermore, they aim at the total dissolution and decomposition of a person in all aspects in this world and in the thereafter. ${ }^{19}$ In the ancient near eastern world, the "erection of a shrine" and the establishment of a "cult for the divine" was a motivation for a blessing and a national economic boom initiated by a Supreme Being. ${ }^{20}$ The socio-economic stability of a nation was explained in terms of people's relations with the cult. Neglect of these would result in curses. $^{21}$ The cult was believed to be attached to the land, and sometimes to the moon. The Supreme Being who gave land to the people to inhabit would provide the rains from the "moon" god for the people to reap harvest. ${ }^{22}$ In that sense, if the cult was dishonoured, the result would be famine in the land, because the gods have been angered and had therefore bestowed curses (e. g. famine, sickness, exile, oppression, and the like) instead of blessings. ${ }^{23}$ Alan Lenzi and Jonathan Stökl attest that if Judah had developed some form of contractual understanding with Assyria, it is likely that the treaty included curses. ${ }^{24}$ In such circumstances, Lenzi and Stökl add, both Judean and Assyrian ideologues and theologians would have understood the Assyrian's action as bestowing curses that would have been understood to have been enforced by at least Assur and Yahweh. ${ }^{25}$ In addition to cursing or threatening to replace rebellious kings and their households in a treaty, the Neo-Assyrian treaties also cursed entire populations, even threatening to deport them. ${ }^{26}$ As for the Jews, Yahweh would inflict curses if the people sinned or deviated from him. Their misfortune was punishment for their sins. ${ }^{27}$

Various other biblical passages attest to the fact that people would be cursed for either being rebellious or disobedient. ${ }^{28}$ The examples below shed

18 Assmann, "Inscriptional Violence and the Art of Cursing," 53.

19 Assmann, "Inscriptional Violence and the Art of Cursing," 53.

20 Rugwiji, “Appropriating Judean Postexilic Literature in a Postcolonial Discourse," 54.

21 Rugwiji, “Appropriating Judean Postexilic Literature in a Postcolonial Discourse," 55 .

22 Rugwiji, “Appropriating Judean Postexilic Literature in a Postcolonial Discourse," 55 .

23 Rugwiji, “Appropriating Judean Postexilic Literature in a Postcolonial Discourse," 55.

24 Alan Lenzi and Jonathan Stökl, Divination, Politics \& Ancient near Eastern Empires (Atlanta: Society for Biblical Literature, 2014), 61.

25 Lenzi and Stökl, Divination, Politics \& Ancient near Eastern Empires, 61.

26 A similar notion is also depicted in the biblical text about the Babylonian captivity of the Judeans. See for example, Ezra 9:6.

27 Izak Spangenberg, "The Job and the Powerless God" in Old Testament Science and Reality (eds. Willie Wessels and Eben H. Scheffler; Pretoria: Verba Vitae, 1992), 305. Rugwiji, "Appropriating Judean Postexilic Literature in a Postcolonial Discourse," 55. 28 See for example, Mitchell Chase, "God's Judgments on His Blessing: How Genesis 1:28 Informs the Punishments of Adam and Eve," JBMW XVIII/1 (2013): 16-21. 
more light on this notion. The human race is cursed for the sin of disobedience on the part of Adam, from whom all humanity is believed to have derived (Gen. 3:15-19). ${ }^{29}$ Because of the sin of Adam, all human beings have inherited Adam's curses such as death and toiling in order to survive. Chase remarks that after Adam and Eve disobeyed God, their punishments brought disruption to manhood and womanhood. ${ }^{30}$ Curse is also portrayed as a consequence of murder. ${ }^{31}$ In the book of Genesis (9:18), we read that Noah had three sons: Shem, Japheth and Ham. Ham had four sons: Cush, Mizraim, Put and Canaan (Gen. 10:6). ${ }^{32}$ Canaan was cursed because his father had seen Noah's nakedness (Gen. 9:25). ${ }^{33}$ Noah said: "Cursed be Canaan! A slave of slaves, a slave to his brothers! Blessed be God, the God of Shem, but Canaan shall be his slave. God prosper Japheth...But Canaan shall be his slave" (Gen. 9:25-27).

Some curses (or misfortunes) were pronounced on individuals or a nation. These include, for example, pestilence, consumption, fever, inflammation, extreme burning, the sword, blasting and mildew (Exod. 28:21-22). ${ }^{34}$ It appears that "cursing" was not exclusive in the Bible; that is, it did not only involve outsiders and or strangers as victims, but also one's own children. Hence, in Deuteronomy 21:23, we read that one who committed a crime worthy of death should be hanged on a tree, in which the "victim"/"criminal" is described as "cursed by God" (Deut. 21:24). We also read in both Exodus (21:15) and

29 See R.J. Berry, “Adam or Adamah?” Science and Christian Belief 23 (2011): 2348; Menachem Krakowski, "Reclaiming the self: Adam's sin and the human psyche," Hakirah: Flatbush Journal of Jewish Law and Though 5 (2007): 151-170.

30 Chase, "God's Judgments on His Blessing," 16-21.

31 See Genesis 4:11 about the cursing of Cain for murdering his brother, Abel.

32 Ross, Allen P. "The Table of Nations in Genesis 10: Its Content," BSac 138 (1980): 22-34.

33 The biblical text shows that the sin of Ham, the youngest son of Noah (Gen.9:24) carried a negative effect, not precisely on Ham, but on Ham's youngest son, Canaan (Gen. 9:25; 10:6). The reason for Noah to pronounce curse on Canaan, Ham's youngest son, and not Ham, the offender, remains unknown. However, one is reminded of a proverb which is common among the Shona people of Zimbabwe that: "Chisi hachiyeri musi wacharimwa" (literally translated: "a negative effect of an offense of violating a sacred day by working will not manifest immediately; it will begin to have an effect on those still living some time later even after the offender has since passed on"). A similar belief is very strong about ngozi (avenging spirit) among the Shona people of Zimbabwe. One can read about Noah's curse of Canaan with the hindsight of the annunciation by the prophets Jeremiah (31:29) and Ezekiel $(18: 2)$ that "... The parents have eaten sour grapes, and the children's teeth are set on the edge". One would therefore speculate that Noah had some idea about what was common among the society of his time with regards to cursing, that it would have an effect on the offender's descendant(s). Hence, Canaan became the victim.

34 Assmann, "Inscriptional Violence and the Art of Cursing," 43-65. 
Deuteronomy (21:16-21) that children would be cursed for striking their parents and for being contemptuous towards their fathers and their mothers.

Elsewhere, biblical texts instruct Israel that serving other gods (and not Yahweh) would result in a curse (Deut. 29:24-28). Job 4:7 indicates that the upright and the innocent do not suffer, suggesting that Yahweh was punishing Job for sinning; Haggai 1:9-11 suggests that the Judeans suffered famine as a result of drought because they had neglected building the temple for Yahweh; Malachi 3:1 states that the Judeans remained cursed and would not prosper as long as they despised paying tithes into the temple treasury; Yahweh had scattered the Israelites among the nations for being unfaithful (Neh. 1:8-9). According to Ezra 9:5-9, the Babylonian captivity happened because the sins of the Judeans were "higher than our heads and our guilt has reached the heavens" $(9: 6)^{35}$.

In some instances, God would curse children for the sins of their "fathers" (Lam. 5:7; Jer. 31:29-30), causing both authors of the books of Jeremiah (31:29) and Ezekiel (18:2) to write that "... The parents have eaten sour grapes, and the children's teeth are set on the edge". ${ }^{36}$ Haggai 1:4-11 also conveys the idea that the neglect to rebuild the Temple resulted in Yahweh inflicting on the Judeans curses such as small harvests, having insufficient food and drink, and lack of warm clothes. ${ }^{37}$ The exile, enslavement, famine that hit the land and the poverty that affected people were all believed to be consequences of neglecting the "house of God" (2 Chr. 36:10-21; Neh. 1:4-10, 5:1-5; 9:3-37; Ezr. 9:5-9).

In the New Testament, the notion of curse is also apparent. The Gospels, Matthew (27:32-56), Mark (15: 21-41), Luke (23:26-49), and John (19:17-37) indicate that God cursed and condemned his son to death on the Cross for the salvation of the sinful human race. ${ }^{38}$ Because God gave his son to the sinful world, the OT curse and other "generational" curses are transferred to Jesus, who is now considered the "cursed one" (John 3:16-17; Gal. 3:13). ${ }^{39}$

\section{E THE PRESENCE OF AN AFRICAN IN THE BIBLE}

Genesis 3:17 reads that: “... cursed is the ground because of you; through painful toil you will eat food from it all the days of your life." We also read that: "Cush will submit herself to God" (Psa. 68:31). The majority of people (especially believing communities) regard the Bible as absolute and entirely authoritative.

\footnotetext{
35 Rugwiji, “Appropriating Judean Postexilic Literature in a Postcolonial Discourse,” 55.

36 Nahum M. Waldman, "Parents Have Eaten Sour Grapes,” JBQ1/69 (1989): 1-5.

37 Rugwiji, “Appropriating Judean Postexilic Literature in a Postcolonial Discourse," 55 .

38 This concept has been contested variously in recent years. I will develop this notion in another study.

39 Morna D. Hooker, "Interchange in Christ,” JTS 22 (1971): 349-361.
} 
These believing communities take seriously the teaching of biblical texts, that human suffering and struggle for survival are consequences of the $\sin (\mathrm{s})$ committed by Adam. ${ }^{40}$ In addition to the claim of biblical texts, numerous scholarly works have also presupposed that Ham's first son Cush represents the Kushites/Cushites who are believed to be the ancestors of the Black people of African origin (including the African Americans). ${ }^{41}$ Although the biblical text does not state Noah's cursing of Cush, the implication that has recently gained momentum is that Black people are the descendants of the biblical Cushites. One wonders whether wars, genocide, poverty and starvation that continue to devastate largely the African continent are a fulfilment of this biblical curse. The ambiguity becomes even more cumbersome when some biblical commentators attempt to connect the identities of the African people with individuals mentioned in the biblical text. Scholars such as Cain H. Felder, ${ }^{42}$ Norman Cohn, ${ }^{43}$ David T. Adamo ${ }^{44}$, Adekunle Dada, ${ }^{45}$ Peter Unseth, ${ }^{46}$ Allen Ross, ${ }^{47}$ Daniel Hays, ${ }^{48}$ and David M. Goldenberg, ${ }^{49}$ among others, have continued to argue for the presence of Africans (Kushites) in the Bible. Felder remarks that European thinkers in the $15^{\text {th }}$ century initially explained the existence of the darkskinned people of Africa within the biblical framework that reified and justified the subservient status of Africans. ${ }^{50}$ Cohn also points out that black Africans descended from one of Noah's sons, Ham, whom Noah had cursed because of a minor transgression committed after the flood. ${ }^{51}$ In light of the above trajectories,

40 Jerome S. Buthelezi, "A Critical Analysis of the Doctrine of Salvation in Free Evangelical Assemblies in Swaziland: A Contextualized Theology" (MTh Dissertation, South African Theological Seminary, 2011), 67.

41 I will return to this argument subsequently.

42 Cain H. Felder, Troubling Biblical Waters: Race, Class and Family (New York: Orbis, 1990), 44

43 Norman Cohn, Noah's Flood: The Genesis Story in Western Thought (New Haven: Yale University Press, 1996), 71

44 David T. Adamo, "The Deuteronomist(s)' Interpretation of Exilic Suffering in an African Perspective," OTE3/1 (2010): 9-27.

45 Adekunle O. Dada, "Repositioning Contextual Biblical Hermeneutics in Africa Towards Holistic Empowerment," Black Theology: An International Journal 8/2 (2010): 160-174.

46 Peter Unseth, "Hebrew Kush: Sudan, Ethiopia, or Where?” Africa Journal of Evangelical Theology 18/2 (1999):143-159.

47 Allen P. Ross, “The Table of Nations in Genesis 10: Its Content," BSac 138 (1980): 22-34.

48 Daniel J. Hays, "The Cushites: A Black Nation in Ancient History," BSac 153/611 (1996): 270-271.

49 David M. Goldenberg, "The Curse of Ham: A Case of Rabbinic Racism?" in Struggles in the Promised Land (eds. Jack Salzman and Cornel West; Oxford: Oxford University Press, 1997), 21-55.

50 Felder, Troubling Biblical Waters: Race, Class and Family, 44.

51 Cohn, "Noah's Flood: The Genesis Story in Western Thought," 71. 
the readership is confronted with the ideology of "Blackness" and the concept of curse in relation to Africa and Africans. Daniel Hays brings us closer to this affirmation by presenting the Kushites as black people who are mentioned about fifty-four times in the Bible. ${ }^{52}$ David Goldenberg describes Black Africans in a derogatory way where he characterises them as: "Physically and intellectually inferior, cursed by God, oversexed, more animal than human, ugly, smelly, and associated with the devil" 53 . Ross, who seemingly supports my argument, also maintains that Africa is indeed a cursed continent ${ }^{54}$. With reference to Ham's four sons, Ross suggests that Cush represents Ethiopians, Mizraim (Egyptians), Put (Somalians and Libyans) and Canaan (Palestinians, Phoenicians, etc) ${ }^{55}$. However, Meiring does not agree with Ross' opinion of Black people as the remnants of $\mathrm{Ham}^{56}$. While the ongoing debate on the presence of Africans in the Bible continues, and the Kushites are believed to be the descendants of Ham through Canaan, the contestation of Africans as cursed arises from experiences of wars, genocide, HIV/AIDS, ${ }^{57}$ poverty, starvation and leadership crises which continue to devastate largely the African continent.

As Awojobi noted, Africans continue to be impoverished, and Africa remains underdeveloped on a continent with an abundance of natural resources ${ }^{58}$. Unless and until African scholarship revises and reverses its position on the presence of Africans in the Bible, and believing communities admit that the biblical text should be reread and reinterpreted with caution, problems presented by the texts, including those of "blessing" some human species and "cursing"

52 Hayes, "The Cushites: A Black Nation in Ancient History," 270-271.

53 See Goldenberg, ““The Curse of Ham: A Case of Rabbinic Racism?” 21-55. This study does not in any way subscribe to Goldenberg's viewpoint as stated above. Nevertheless, Goldenberg, in my view, comments on theories already circulating regarding "Blackness" and "Africanness." However, the point this essay attempts to emphasize is the question of how the readership and biblical commentators interpret the theme of curse in relation to postbiblical societies, race in particular and the creation of humans in general.

54 Ross, "The Table of Nations in Genesis 10: Its Content,"22-34.

55 Ross, "The Table of Nations in Genesis 10: Its Content," 22-34.

56 Jacob J.S. Meiring, "Shem, Ham, Japheth and Zuma - Genesis 9:25-27 and Masculinities in South Africa," Stellenbosch Theological Journal 2/1 (2016):223-240.

57 It is an actuality that the HIV/AIDS pandemic has caused the death of people not only among the Shona people but the world over. See Dennis Masaka and Agrippa Chingombe, "The Relevance of 'Gata' Among the Shona of Zimbabwe in the Context of the HIV/AIDS Pandemic," Journal of Pan African Studies 3/1 (2009):190.

58 Nathaniel O. Awojobi, "Corruption and Underdevelopment in Africa: A Discourse Approach," International Journal of Economics, Commerce and Management 2/10 (2014): 5. 
others, will remain unresolved. Hence, the Dobzhansky' theory on the origin and development of human species may be taken into account. ${ }^{59}$

\section{F INDIGENOUS KNOWLEDGE SYSTEMS}

IKS is the knowledge systems developed by a community as opposed to the scientific knowledge that is generally referred to as "modern" knowledge ${ }^{60}$. Within an international context, the term "indigenous" is understood (mostly by Europeans) as being similar or synonymous to "traditional", "aboriginal", "vernacular", "African", "Black", and "native American" 61 . However, indigenisation should not be used as an inclusion and exclusion mechanism. For example, the aggressive revolution of promoting "indigenisation" by promulgating the Indigenous and Empowerment Act which requires foreign companies to award 51 percent of their ownership to indigenous Zimbabweans ${ }^{62}$. IKS is a critical strategy towards fostering, implementing and strengthening African cultural heritage. ${ }^{63}$ Arowolo affirms that civilisation can also be used in a normative way to indicate cultural superiority of one group or country over another. ${ }^{64}$

Nevertheless, Mutema pleads for IKS methodologies that are not driven by blind assertion of African ideas and concepts in order to replace the Western terms without critical reflection ${ }^{65}$. The above assertion emerges against a backdrop of criticisms against former colonial masters for the deterioration of standards of living among Africans. To some extent, the above assertion cannot be "swept under the carpet." For example, the Dutch Reformed Church in Mashonaland was generally known to be negative towards indigenous forms of religious expression ${ }^{66}$. However, Africans, in my view, need to stop being "crybabies". The argument of the present article concurs with Briggs' question:

59 Theodosius Dobzhansky, Mankind Evolving. The Evolution of the Human Species (London: Yale University Press, 1962), xiii, 381.

60 Lanre T. Ajibade, “A Methodology for the Collection and Evaluation of Farmers' Indigenous Environmental Knowledge in Developing Countries," Indilinga: African Journal of Indigenous Knowledge Systems 2(2003):99-113.

61 J. A. (Bobby). Loubser, "Unpacking the Expression "Indigenous Knowledge Systems," Indilinga: African Journal of Indigenous Knowledge Systems 4/6 (2005):76. 62 Rugwiji, "Appropriating Judean Postexilic Literature in a Postcolonial Discourse," 255.

63 Shadreck Chirikure, "Heritage Conservation in Africa: The Good, the Bad, and the Challenges," South African Journal of Science 109/1-2 (2013):1-3.

64 Dare Arowolo, "The Effects of Western Civilisation and Culture on Africa," Afro Asian Journal of Social Sciences 1/1 (2010): 1-13.

${ }^{65}$ Gaudencia Mutema, "Phenomenology, Hermeneutics and the Study of Indigenous Knowledge," Indilinga: African Journal of Indigenous Knowledge Systems2/1 (2003):81.

66 Steven Kaplan, "The Africanisation of Missionary Christianity: History and Typology," Journal of Religion in Africa 16/3 (1986):173. 
"If indigenous knowledge is so good, why is my farm so poor?"67 In spite of indigenisation and independence being celebrated in the African continent at large, including ownership of land, the arguments raised in this discussion tend to demonstrate that Africa still has a great deal of "homework" to do to in order to become a force to reckon with.

\section{G PROTEST WRITING ${ }^{68}$}

In this article, an attempt is made to provide representative examples of "protest writings" that have recently dominated African scholarship. In terms of "protest writing," particular reference is made to contributions that depict the notion that postcolonial Africa continues to experience various layers of political and socioeconomic crises because of the continent's historical past and the colonial distortions exerted on Africa by Europeans and their allies. A few examples of "protest writings" will suffice. Dare Arowolo writes that colonialism, slave trade and missionaries are the bastion of Western civilisation and culture in Africa ${ }^{69}$ .It is not inappropriate for Arowolo to assert that colonialism served as a vehicle of implantation of cultural imperialism in Africa. For Arowolo Africans became "westernised" as a result of the importation of western culture and European mode of civilization. ${ }^{70}$ Kwame Nantambu also notes that European and EuroAmerican scholars were, in the past guilty, of racist or race-based pseudoscience regarding the history and prehistory of Africa. ${ }^{71}$ In my view, Nantambu's view similarly suggests that in the absence of the distortions on African history by European scholars, African history and culture would have been preserved. However, one wonders whether this would have been possible during prehistoric times in Africa before the advent of technology of reading and writing, which was exported to Africa by Europeans and Westerners. However, one could also argue that our postmodern world is better, faster, manageable and creative than it was during prehistoric times because culture, as Amani Buntu observes, is not

67 Briggs, "The use of Indigenous Knowledge in Development: Problems and Challenges," 99-114.

68 Earlier on this study (see "counterproductive" and "retrogressive" in the Introduction), I made reference to an "introspection" (self-examination) as a critical component of the present discussion. I can as well safely state it here that "protest writing", in my view, tends to shift attention (hence, "blame-game") on other people for causing political and socioeconomic crises devastating either the African continent as a whole, Zimbabwe as a nation or individuals. The present discourse has deliberately avoided an in-depth discussion on "protest writing" which will be explored in a future research. In view of the initial draft, this section is just an overview of "protest writing". 69 Dare Arowolo, "The Effects of Western Civilisation and Culture on Africa," Afro Asian Journal of Social Sciences 1/1(2010): 1

70 Arowolo, "The Effects of Western Civilisation and Culture on Africa," 1.

71 Kwame Nantambu, "Egypt and European Supremacy," A Current Bibliography on African Affairs 28/4 (1996/7): 357-379. 
static. ${ }^{72}$ Monhla also affirms that it is impossible to separate what exactly has been distorted by the white enterprise, considering the nature of colonialism, imperialism, dispossession, and dehumanisation in Africa. ${ }^{73}$ For Ngambi to presuppose that Africa appears to be caught in a developmental pause: underdevelopment, poverty, poor health, unemployment characterise Africa, he is in a way saying Africa is not moving forward economically and culturally. ${ }^{74}$ Another type of "protest" includes Robert Mugabe's speech, namely: "Blair, keep your England and I will keep my Zimbabwe". ${ }^{75}$ Mugabe's speech serves to elucidate that political rhetoric is just meant to deliberately exhilarate a certain section of society, because one cannot reconstruct the significance and relevance of the statements to post-independence Zimbabwe's socioeconomic development. Elsewhere, some contributions have continued to protest for the change of place names in Zimbabwe, which neither addresses livelihood complexities in any way, nor enhances socioeconomic development towards poverty reduction among communities. ${ }^{76}$

\section{H NATURAL RESOURCES IN ZIMBABWE}

Previously in this article, I alluded to the fact that the theme (metaphor) of curse drawn from the narrative of Noah cursing his grandson, Canaan (Gen.9:25), ${ }^{77}$ is appropriated in the African (Zimbabwean) context. Although narrative inquiry research is utilised, hermeneutics of appropriation ${ }^{78}$ is also used in which themes from biblical texts are discussed in response to complexities affecting humans. Because the Bible is widely read and interpreted within a given context among communities in Africa, biblical narratives such as Adam's sin and fall have been interpreted to mean that the land and its natural resources have been cursed

72 Amani O. Buntu, "Rape, Rage and Culture: African Men and Cultural Conditions for Justification of and Sanctions against Rape" (MEd Diss., University of South Africa, 2012), 56.

73 Elias Monhla, "Africanisation within the URCSA: A Critical Focus on How the Church Order Relates to African Marriages" (MA Diss., University of Pretoria, 2014), 43.

74 Hellicy Ngambi, "Rare Leadership: An Alternative Leadership for Africa," International Journal of African Renaissance Studies 6/1 (2011):7.

75 Sabelo J. Ndlovu-Gatsheni, "Making sense of Mugabeism in Local and Global Politics: 'So Blair, Keep Your England and Let Me Keep My Zimbabwe,'” Third World Quarterly 30/6 (2009):1139.

76 See for example, Jacob Mapara and Shumirai Nyota, "Suburban Blight: Perpetuating Colonial Memory through Naming in Mutare, Zimbabwe" in The Postcolonial Conditions of Names and Naming Practices in Southern Africa (eds. Oliver Nyambi, Tendai Mangena and Charles Pfukwa; Cambridge Scholars Publishing, 2016), 289-306.

77 Ross, "The Table of Nations in Genesis 10: Its Content," 22-34.

78 Rugwiji, "Appropriating Judean Postexilic Literature in a Postcolonial Discourse," 6. 
because of the sin of the first man to be created, Adam (Gen. 1:27-28; 2:7-8). The present study engages both the biblical text and biblical commentators by arguing that such an interpretation tends to present a scenario of a natural resource curse in Africa in general and Zimbabwe in particular. In view of the narratives surrounding the beginning of the cosmos and humans occupying it, the readership is confronted with a theological-ecological debate, which Ulrich Körtner prefers to call "ethics of the earth"79. As is the case with the majority of African nations, Zimbabwe's wealth derives largely from the natural resources of the land. According to Duri, Stray-Pedersen and Muller, Zimbabwe boasts abundant natural resources that include nine million hectares of arable land and more than five million hectares of forests, natural parks, and wildlife estates ${ }^{80}$. They further assert that the country is adored for its extensive and varied mineral resources such as platinum, gold, asbestos, coal, nickel, iron, copper, and precious gems such as emeralds and diamonds ${ }^{81}$. Sachs and Warner concur that natural resource abundance is regarded as a determinant of growth ${ }^{82}$. Natural resource exports are defined as the sum of exports of primary agriculture, fuel and minerals ${ }^{83}$

\section{$.1 \quad$ Natural Resource Curse in Zimbabwe}

A natural resource curse occurs when communities become increasingly poorer in a country endowed with abundant natural resources. Africa is rich with natural resources, yet African countries demonstrate low economic growth. ${ }^{84}$

Zimbabwe's "indigenisation policy" is a case study that shows that indigenisation through "land grabbing" is far from a success story. Almost two decades have lapsed since the land reform exercise was implemented in Zimbabwe ${ }^{85}$.However, until recently (at the time of concluding this research in May 2018), Zimbabweans live in poverty and starvation, industries have closed, and the economy has collapsed. One would, therefore, question the legitimacy of the implementation of the indigenisation in Zimbabwe and elsewhere in

79 For further reading, see Ulrich Körtner, "Ethics of the Earth and Creation Faith," HTS 72/4 (2016): a3296. http://dx.doi.org/10.4102/hts.v72i4.3296.

80 Kerina Duri, Babill Stray-Pedersen and F. Muller, "HIV/AIDS: Zimbabwean Situation and Trends," The American Journal of Clinical Medicine Research 1/1 (2013): 15 .

81 Duri, Stray-Pedersen and Muller, "HIV/AIDS: Zimbabwean Situation and Trends", 15.

82 Jeffrey D. Sachs and Andrew M. Warner, "Sources of slow growth in African economies," Journal of African Economies6/3 (1996):341.

83 Sachs and Warner, "Sources of slow growth in African economies," 341.

84 Elissaios Papyrakis and Reyer Gerlagh, "The Resource Curse Hypothesis and its Transmission Channels," Journal of Comparative Economics 32/1 (2004): 181-193.

85 Rugwiji, “Appropriating Judean Post-Exilic Literature in a Postcolonial Discourse," 32. 
Africa. Against this background, is also a resurfacing of a colonial system this time with a different, yet a familiar personality that is determined towards subjugating postcolonial communities that continue to remain on the margins ${ }^{86}$.

With reference to the notion of curse among Africans, this research refers to the way of thinking and doing things in Africa, demonstrated by a lack of rationality to distinguish the difference between right and wrong. Some African nations gained independence more than fifty years $\mathrm{ago}^{87}$. However, it is unfortunate that many African countries are still finding it difficult either to sustain what they inherited from colonial governments or to come up with new innovations towards developing their respective economies. Julius Nyerere was right to challenge the then Prime Minister Robert Mugabe when Zimbabwe gained independence from Rhodesia in 1980 in the sense that: "You have inherited a jewel; keep it" 88 .Unfortunately, 37 years later, Zimbabwe's legacy as the "breadbasket of Southern Africa" 89 has been destroyed. Hence, Greg Mills laments that sub-Saharan African countries have not fulfilled their potential since independence ${ }^{90}$. Africa is largely dependent on Western and European thought patterns in which economic powerhouses continue to play the critical role of a catalyst in salvaging Africa's dwindling economies as well as functionaries towards the introduction of technological and industrial revolution even in the modern postcolonial Africa. For example, in Zimbabwe, the minority white population comprising about four thousand commercial farmers enhanced the economy of the country of about 12 million (according to 2002 census, Zimbabwe's population was 11.6 million people $\left.{ }^{91}\right)$. After the notorious

86 Emmerson Mnangagwa is now new President of the Republic of Zimbabwe after the ousting of Robert Mugabe. Previously, Mnangagwa was vice-President who was sacked by Mugabe. The question that everyone is asking is the constitutionality of the assumption of power by Mnangagwa in the absence of democratic elections. At the time of concluding this research in May 2018, the dates for the 2018 elections were not announced, yet. Mnangagwa assumed the position of Presidency before the endorsement as the party's 2018 presidential candidate at the ZANU (PF) 2017 Annual Congress.

87 Martin Meredith, The Fate of Africa: From the Hopes of Freedom to the Heart of Despair-A History of Fifty Years of Independence (New York: Public Affairs, 2006), 752.

88 Temba T. Rugwiji, "Reading the Exodus Tradition from a Zimbabwean Perspective" (MA Diss., University of South Africa, 2008), 133.

89 Edward Shizha and Michael T. Kariwo, Education and Development in Zimbabwe: A Social, Political and Economic Analysis (Rotterdam: Sense Publishers, 2011), 4

90 Greg Mills, "Why Is Africa Poor?" Development Policy Briefing Paper No. 6. Centre for Global Liberty and Prosperity (6 December, 2010), 1.

91 Duri, Stray-Pedersen and Muller, "HIV/AIDS: Zimbabwean Situation and Trends", 15 . 
widespread farm invasions and expulsion of white farmers, the country became poorer and poorer over about two decades. ${ }^{92}$

Indigenous farmers who acquired the land did not have the resources and the expertise to conduct proper farming activities. For example, the businessman-turned-football administrator, Phillip Chiyangwa, occupied a farm near Chinhoyi in Mashonaland West Province, about $120 \mathrm{~km}$ northwest of Harare, Zimbabwe's capital. A source who chose to remain anonymous was contracted by Chiyangwa to repaint his farmhouse. The source revealed that no serious farming activities were taking place on the farm, and farm workers had to provide their services without remuneration ${ }^{93}$. Obstacles to the agricultural sector are further compounded by vandalism of modern farming equipment left behind by evicted commercial farmers". If Zimbabweans were "smart" and "knowledgeable", they would manage farming equipment and machinery following the land reform for the sustenance of the economic development of the nation as a whole after the expulsion of white commercial farmers ${ }^{95}$. In addition, the natural vegetation continues to be threatened by man-made deserts, because trees continue to disappear as the market for firewood grows ${ }^{96}$. The argument by some critics that Africans are cursed might also be extended to include the level of ignorance demonstrated through indiscriminate destruction and looting of natural resources without considering the negative impact such actions would have on agricultural productivity. In addition to desertification, the indiscriminate felling of trees can also cause serious land degradation and soil erosion. Continuous soil erosion would "sweep" away the rich soil and ingredients needed by crops. Zimbabwe is agro-economy. Hence, for close to twenty years, Zimbabwe was incapacitated to export agricultural products due to the haphazard agrarian reform.

Generally, critics have argued that Africa is known for being a consumer of Western products, and a producer and exporter of very little. For example, with regards to knowledge technology, one could consider the manufacture of

92 Rose C. Sakuhuni, Clainos Chidoko, Netsai L. Dhoro, and Caleb Gwaindepi, "Economic Determinants of Poverty in Zimbabwe," International Journal of Economic Research 2/6 (2011):1-12.

93 The source, who also painted my house located in Ruvimbo Phase 1 in Chinhoyi in July and December 2017, revealed that the few farm workers employed by Chiwanga have been working for years without wages. According to sources, the plight of the farm workers is deliberately denied media coverage because it will expose the false notions of land reform.

94 See Moore, "Progress, power and violent accumulation in Zimbabwe," 6.

95 Rugwiji, “Appropriating Judean Post-Exilic Literature in a Postcolonial Discourse: A Case for Zimbabwe," 32.

96 An anonymous source has revealed that firewood used by urban consumers to extract energy for various domestic and or industrial needs are sold to merchants by newly-settled farmers. 
aircraft, ships, smartphones, microscope, satellite, cars, computer software, and digital equipment, among others, which are manufactured by firms outside the African continent. Those who have visited destinations such as Europe, the USA, Asia, and so forth can marvel at the advanced levels of technology that characterise these destinations. Those who have travelled by sea may have been exposed to the splendour of modern ships and submarines. Superior cars such as Mercedes Benz, BMW and VW (which certain individuals among Africans identify with prestige and supremacy) are manufactured in Germany. Until now, IKS in Africa is not nearly au fait with the technology exhibited by European/American knowledge systems.

Closer to home, in South Africa, ex-president Thabo Mbeki pioneered what he called an "African Renaissance". ${ }^{97}$ Mbeki proposed a rebirth of the African continent and critiqued the mixture of greed, dehumanising property, obscene wealth and endemic public and private corruption as drawbacks to Africa's socioeconomic development ${ }^{98}$. Mbeki's proposal painstakingly attempted to demonstrate preparedness towards transformation of an African society that truly engenders its Africanness. One could concur with Curtboys that the history of experiences and identity formations may help societies to reconstruct their future and their destiny ${ }^{99}$. Oluwole also confirms that Africans cannot continue to ignore their intellectual past if they are sincerely interested in promoting the development of a meaningful contemporary tradition of their discipline. ${ }^{100}$

However, Zimbabwe's history has been plunged into a state of being cursed, unable to solve socioeconomic problems that are devastating the majority of citizens. In Africa, the term "democracy" exists in theory but not in practice. It is only in Africa where one is eliminated through disappearances and death for demanding justice ${ }^{101}$. In addition, Africa is often characterised by electionrelated violence and killings (representative examples being Togo [2005], Democratic Republic of Congo [2006], Lesotho [2007], Nigeria [2007], Kenya [2007/8], and Zimbabwe [2008]), ${ }^{102}$ among others.

97 Thabo Mbeki, Africa - The Time Has Come (Cape Town: Tafelberg, 1998), 298.

98 Mbeki, Africa - The Time Has Come, 298.

99 Ann Curtboys, Freedom Ride: A Freedom Rider Remembers (Sydney: Allen \& Unwin, 2002), 1.

100 Bosede S. Oluwole, "Oruka's Mission in African Philosophy," In Sagacious Reasoning (eds. H. Odera Oruka, Anke Graness and Kai Kresse; Nairobi: East African Educational Publishers, 1997), 161.

101 Lorna Davidson and Raj Purohit, "The Zimbabwean Human Rights Crisis: A Collaborative Approach to International Advocacy," Yale Human Rights and Development Journal 7/1 9 (2004): 110.

102 Dimpho Mostamai, "When Elections Become a Curse: Redressing Electoral Violence in Africa," EISA Policy Brief 1 (2010): 1. 
It is, also, only in Africa where the leadership embarks on a long-term revolution of "indigenisation" without counting the cost. As Heather Chingono observes, Zimbabwe's land redistribution exercise was a disaster because the government miscalculated the reactions of both the whites occupying the farms at the time and the international community which sympathized with evicted commercial farmers ${ }^{103}$. When an African assumes a position of power, it seems, he perpetuates the same ideology (or worse still) which he previously opposed ${ }^{104}$.

In Zimbabwe, for example, the political game is not played according to the rules ${ }^{105}$. It is argued elsewhere that "to be educated is one thing", and "to be learned" is completely another ${ }^{106}$. If the Bible is relied upon as the source of information about the creation of the human race in general, and Africans in particular, the contestation for Africa and Africans being cursed will continue to present ambiguities.

\section{CHITUKO/NGOZIAMONG THE SHONA PEOPLE}

Wächter maintains that the Israelite culture occupies a special place when it comes to the views concerning death and afterlife ${ }^{107}$. Among African cultural societies, the death of a person is defined in terms of either an angered spirit of the ancestors, witchcraft or a curse such as chituko or ngozi. John Mbiti says is

${ }^{103}$ Heather Chingono, 'Zimbabwe Sanctions: An Analysis of the 'Lingo' Guiding the Perceptions of the Sanctioners and the Sanctionees," African Journal of Political Science and International Relations 4/2 (2010):066-074.

104 Norman Gottwald (1985:375) explains that the leaders of the Judean society were responsible for the deterioration of the old tribal order of communal equity. Both people and property were violated by these leaders in enriching themselves and strengthening their position of power. Abuse of office and power by those in positions of influence appears to be a human problem among postbiblical societies in general, and Zimbabwe in particular.

${ }_{105}$ Zimbabwe is currently under military rule following the ouster of President Robert Mugabe who had been in power for 37 years, from 1980 to 2017. However, army chiefs were reluctant to pronounce their action as a "cool" fearing that the international community would not recognize the government, and would slap the "new regime" with bilateral and economic sanctions.

106 A learned person is someone who has successfully understood certain instructions to accomplish a specific task or set of tasks, but when it comes to other tasks (no matter how relevant they are!) he can easily be confused and even frustrated! While an educated man is someone who has successfully formed a flexible broad understanding of the universe by putting the different pieces of the puzzle together (Some science mixed with history plus a touch of art and with a lot of philosophy!); and there's hardly any task that could confuse such a man. See Mohamed Khedr, "Is there any difference between someone who is educated and someone learned?" Online:

https://www.bayt.com/en/specialties/q/69021/is-there-any-difference-betweensomeone-who-is-educated-and-someone-learned/. Accessed 17 December 2017. 107 Ludwig Wächter, Der Tod im alten Testament (Stuttgart: Calwer Verlag, 1967). 
best when he notes that: "When someone has died, people often try to find out who used sorcery, witchcraft or magic against the dead person"108. Adamo reaffirms the similarities that exist between Yahweh punishing Israel for sinning by allowing the invasion, and loss of the land by Africans to foreigners because they sinned against the gods. ${ }^{109}$

Although Adamo refers particularly to the Nigerian context, such belief systems are also common in other African cultures, such as the Shona people of Zimbabwe where the gods through "vadzimu" (spirit mediums) can inflict calamities such as loss of land if people profane the sacred ${ }^{110}$. Spronk affirms that unlike the Hittites and the peoples of Mesopotamia, the Israelites did not seem to be familiar with a cult of the dead, in which the deceased ancestors are venerated and believed to have divine power to help or harm the living ${ }^{111}$. Although Israelite culture could have been influenced to some extent by other cultures of the ancient Near Eastern world, the Torah prohibited Israel from venerating the dead.

In Leviticus 21 we read that a normal priest is not allowed to touch a dead person other than close relatives ${ }^{112}$. A high priest was not allowed to come close to a dead person, because too much attention to death and the dead detracts from the correct veneration of the God of Israel ${ }^{113}$. The ancient Israelites seemed to react to death in a "modern" way, especially in their sober acceptance of death as a reality ${ }^{114}$. Death was not viewed as the door to a life after death, but primarily as the conclusion of this life ${ }^{115}$. Hence, Israel did not believe in avenging spirits.

108 John S. Mbiti, Introduction to African Religion (Cape Town: Heinemann International Literature \& Textbooks, 1975), 117.

109 By the phrase "sinned against the gods", the scholar attempted to illustrate for the readership what is common among African societies who believe in Supreme Beings (the local gods). It is generally believed that the local gods were angered by the religiocultural distortions by Africans; hence, the invasion and colonisation of Africa by the Western powers (foreigners). See Adamo, "The Deuteronomist(s)' Interpretation of Exilic Suffering in an African perspective," 9-27.

110 Mircea Eliad, The Sacred and the Profane: The Nature of Religion (New York: Brace and World, Inc, 1963), 20.

111 Klaas Spronk, "Good Death and Bad Death in Ancient Israel According to Biblical lore," Social Science and Medicine 58 (2004):987-995.

112 Spronk, "Good Death and Bad Death in Ancient Israel According to Biblical Lore," 987-995.

113 Spronk, "Good Death and Bad Death in Ancient Israel According to Biblical Lore," 995.

114 Spronk, "Good Death and Bad Death in Ancient Israel According to Biblical Lore," 995.

115 Spronk, "Good Death and Bad Death in Ancient Israel According to Biblical Lore," 995. 
From an IKS perspective, among the Shona people of Zimbabwe, as in ancient Israel, ${ }^{116}$ a bad omen (or ngozi) has a cause. The Shona believe in the potency of curse or ngozi inflicted by either the spiritual world of dead ancestors or through witchcraft ("huroyi") by either neighbours or traditional ritual by one's relatives. In this article, the notion of a curse (chituko) is discussed interchangeably with ngozi. Chituko is a consequence of either beating up one's parents (especially mother), ${ }^{117}$ stealing or murder. Among African cultures in Zimbabwe, the spirit of a person does not completely die. The Shona people always perceive that "mushonga we ngozi kuiripa" (the only solution to appease the avenging spirit is reparation or restitution). ${ }^{118}$

Technically, ngozi is the spirit of a person who has been murdered and then comes back to seek revenge in the family of the murderer by causing unfathomable sorrow through illnesses, misfortunes, or a series of deaths until the perpetrator pays reparations to the offended family. ${ }^{119}$ Munyaradzi Mawere confirms that ngozi is predicated on the idea of "teat for tat" ${ }^{120}$. For example, it is widely believed in Zimbabwe that the spirit of a person who was murdered or not adequately buried can afflict and even possess members of the lineage of the person responsible ${ }^{121}$. Although Schmidt revealed that ngozi can be appeased through appropriate healing rituals, the disastrous consequences of chituko would include "kutanda botso" (wandering as a result of mental disorder), "hungomwa" (barrenness), "hurovha" (joblessness), "kurwara-rwara" (persistent illness), and "ndufu" (deaths), among other curses ${ }^{122}$. In that sense, for a typical African, the results of killing of any form are avoidable. It is believed that even if a person is sentenced to a jail term for murder, ngozi continues to torment the killer during and after serving the jail term, until ngozi is ritualised and an appropriate compensation made. For Pentecostal churches to perform

\footnotetext{
116 Proverbs 26:2 reads, "Like a sparrow in its flitting and a swallow in its flying, so a curse without a cause cannot alight."

117 According to the patriarchal African culture, a wife remains "an outsider" who joins the man's family through matrimony and becomes part of it through birth.

118 Itai Muwati, Zifikile Gambahaya and Fainos Mangena, "Echoing Silences as a Paradigm for Restorative Justice in Post-Conflict Zimbabwe: A Philosophical Discourse," Zambezia XXXIII i/ii (2006): 6

119 Munyaradzi Mawere, "Life-After Bodily Death: Myth or Reality?" The Zambezia Journal of Humanities 32/2 (2005): 26-46; Pamela Reynolds, "Children of Tribulation: The Need to Neal and the Means to Heal War Trauma," Africa 60/1 (1990):1-38.

120 Munyaradzi Mawere, "Indigenous Knowledge Systems (IKS) for Establishing a Moral, Virtuous Society: Lessons From Selected IKSs in Zimbabwe and Mozambique," Journal of Sustainable Development in Africa 12/7 (2010): 218.

121 David Lan, Guns and Rain: Guerrillas Mediums in Zimbabwe (Harare: James Currey Publishers, 1985), 35.

${ }^{122}$ Heike Schmidt, "Healing Wounds of War: Memories of Violence and the Making of History in Zimbabwe's Most Recent Past," Journal of Southern African Studies 23/2 (1987):302.
} 
what they call "demon-casting" on a person who has been cursed may need further research. ${ }^{123}$ Among Pentecostal Christians, the blood of Jesus is regarded as reversing all forms of misfortunes linked to witchcraft, sorcery, disease, unemployment, barrenness, and gender barriers ${ }^{124}$. However, it is believed that even if the wrongdoer and or other blood relatives are converted to Christianity, the chituko/ngozi will continue its menace until compensation is made.

The victim of murder needs to be replaced by compensation in the form of a herd of cattle and a virgin girl, if the murdered person was a man, and a herd of cattle and a small boy, if the murdered person was a woman ${ }^{125}$. In this case, one would talk of compensation in view of the concept of restorative justice ${ }^{126}$. Ngozi can also be considered as a consequence of beating up one's mother. In numerous instances, children (as they grow up into adulthood among the Shona) are told that "amai havarohwi" (literally, "it is a taboo to strike one's mother"). Chituko/ngozi can haunt the guilty person for the rest of their life until a traditional ritual involving a traditional healer (also known as a "witchdoctor") is conducted towards reparation ${ }^{127}$.

\section{J CONCLUSION}

In this article, the concept of curse in biblical texts was explored from IKS perspectives. It was demonstrated that the Hebrew Bible presents two categories of cursing of the humankind: (1) the entire human race was cursed because of the $\sin / \mathrm{s}$ of the first people to be created, Adam and Eve, and (2) Ham (Noah's youngest son) had four sons: Cush, Mizraim, Put and Canaan. Noah cursed his grandson (Canaan), because Ham did not cover his father's nakedness when Noah was drunk. Although it is not stated in the biblical text, it is believed by some scholars that Noah's curse against Canaan was also extended to his other grandchild, Cush (which means "Black"). It was shown that various scholars present Cush as an ancestor of Africans ("Ethiopians")/Black people. Some scholars maintain that this suggests black people in the biblical text. Such a stance further provokes the arguments of socioeconomic and geopolitical crises devastating humans (particularly Africans) as consequences of curse.

123 Francis Machingura and Godfrey Museka, "Blood as the Seat of Life: The Blood Paradox among Afro-Christians," Perichoresis 14/1 (2016):59.

${ }^{124}$ Machingura, "Blood as the Seat of Life: The Blood Paradox among AfroChristians," 59.

125 Mawere, "Indigenous Knowledge Systems (IKS) for Establishing a Moral, Virtuous Society: Lessons From Selected IKSs in Zimbabwe and Mozambique," 218.

126 Muwati, Gambahaya, and Mangena, "Echoing Silences as a Paradigm for Restorative Justice in Post-Conflict Zimbabwe: A Philosophical Discourse," 5.

127 Shirley A. Thorpe, African Traditional Religion (Pretoria: University of South Africa, 1991), 57. 
The article also indicated that a literal reading of biblical texts portrays humankind as cursed because the majority of the readership to date believe the biblical view of creation. Because the Bible is often read literally, the narrative of the creation of the first people, Adam and Eve, and their fall is regarded as authoritative. Taking the above ideas into consideration, it was argued that one cannot read these narratives without suggesting that humans, particularly Africans, are cursed. Unless the position of the biblical texts with regards to creation of humanity is revised and interpreted differently, the metaphor of curse among Africans will likely continue to provoke the question of disparity with regards to the identity and the origin of humankind.

Informed by the above deliberations as the "red thread", the article then proceeded to appropriate the biblical theme of curse in the African context; hence, the phrase "natural resource curse." It was argued that Africa and Africans are poor, yet the continent is rich and endowed with various types of natural resources. It was argued that Africa does not have the capacity to work on its raw materials from natural resources. Because of this lack of capacity, raw materials are exported to developed countries where they are processed into finished products and sold back to Africa. In addition, it was explained that IKS is more of a theory which does not transcend into praxis. IKS should "graduate" into a technologically-oriented discipline which will create job opportunities and manufacture goods and services that can be exported to overseas markets. An example of foiled indigenisation policy in Zimbabwe was also given, particularly the agrarian reform. It was argued that four thousand white commercial farmers enhanced Zimbabwe's agro-economy. Following the eviction of white commercial farmers which commenced in the early 2000s, and new African farmers taking over (who are in the majority), the Zimbabwean economy continues to crumble. The essay further contended that Africa must begin to move away from being a beneficiary to becoming a benefactor. In other words, the continent cannot continue to depend on foreign aid. Further still, it was reiterated that "protest writing" has a potential of being retrogressive. Reference was made to Robert Mugabe, former president of Zimbabwe, and his "famous" protest speech, namely: "Blair, keep you England and I will keep my Zimbabwe". The speech did not contribute substantially to the country's economic development.

The article then proceeded to another layer of curse (that is, chituko/ngozi) among the Shona people of Zimbabwe. It was explored that among the Shona people, one can be cursed for striking a parent, stealing livestock such as cattle, goats and chickens, and for killing, among other forms of offences. Consequences of chituko/ngozi can assume various forms such as kutanda botso, hungomwa, hurovha, kurwara-rwara and ndufu, among others. The study has contended that among the Shona people, it is strongly believed that mushonga we ngozi kuiripa. 
384 Rugwiji, “Conceptualising Biblical View of Curse,” 31/2 (2018): 363-388

\section{BIBLIOGRAPHY}

Adamo, David T. "The Deuteronomist(s)' Interpretation of Exilic Suffering in an African Perspective." Old Testament Essays 3/1 (2010): 9-27.

Ajibade, Lanre T. "A Methodology for the Collection and Evaluation of Farmers' Indigenous Environmental Knowledge in Developing Countries." Indilinga: African Journal of Indigenous Knowledge Systems 2 (2003): 99-113.

Arowolo, Dare. "The Effects of Western Civilisation and Culture on Africa." Afro Asian Journal of Social Sciences 1/1(2010): 1-13.

Assmann, Jan, "Inscriptional Violence and the Art of Cursing: A Study of Performative Writing." Stanford Literature Review 8 (1992): 43-65.

Awojobi, Nathaniel O. "Corruption and Underdevelopment in Africa: A Discourse Approach." International Journal of Economics, Commerce and Management 2/10 (2014): 1-14.

Baumgarten, Albert I. "Myth and Midrash: Genesis 9:20-29." Pages 55-71 in Christianity, Judaism, and Other Greco-Roman Cults: Studies for Morton Smith at Sixty. Edited by Jacob Neusner et al. Leiden: Brill, 1975.

Berry, R.J. “Adam or Adamah?” Science and Christian Belief 23 (2011): 23-48.

Briggs, John. "The Use of Indigenous Knowledge in Development: Problems and Challenges." Progress in Development Studies 5/2 (2005): 99-114. https://doi.org/10.1191/1464993405ps105oa

Bissell, C. William. "Engaging Colonial Nostalgia". Cultural Anthropology 20/2 (2014): 215-248. https://doi.org/10.1525/can.2005.20.2.215

Buntu, O. Amani. "Rape, Rage and Culture: African Men and Cultural Conditions for Justification of and Sanctions against Rape." MEd Diss., University of South Africa, 2012.

Buthelezi, S. Jerome. "A Critical Analysis of the Doctrine of Salvation in Free Evangelical Assemblies in Swaziland: A Contextualized Theology." MTh Dissertation, South African Theological Seminary, 2011.

Chase, Mitchell. "God's judgments on his blessing: How Genesis 1:28 Informs the Punishments of Adam and Eve." The Journal for Biblical Manhood \& Womanhood XVIII/1 (2013):16-21

Chingono, Heather. 'Zimbabwe Sanctions: An Analysis of the 'Lingo' Guiding the Perceptions of the Sanctioners and the Sanctionees." African Journal of Political Science and International Relations 4/2 (2010):066-074.

Chirikure, Shadreck. "Heritage Conservation in Africa: The Good, the Bad, and the Challenges." South African Journal of Science 109/1-2 (2013): 1-3. https://doi .org/10.1590/sajs.2013/a003

Clandinin, Jean D. and Connelly, Michael F. Narrative Inquiry: Experience and Story In Qualitative Research. San Francisco: Jossey-Bass, 2000.

Cohn, Norman. Noah's Flood: The Genesis Story in Western Thought. New Haven: Yale University Press, 1996. https://doi.org/10.2307/j.ctt1ww3vpn

Curtboys, Ann. Freedom Ride: A Freedom Rider Remembers. Sydney: Allen \& Unwin, 2002.

Dada, Adekunle O. "Repositioning Contextual Biblical Hermeneutics in Africa Towards Holistic Empowerment." Black Theology: An International Journal 8/2 (2010):160-174. https://doi.org/10.1558/blth.v8i2.160 
Davidson, Lorna and Purohit, Raj. "The Zimbabwean Human Rights Crisis: A Collaborative Approach to International Advocacy." Yale Human Rights and Development Journal 7/1 9 (2004):108-131.

Dobzhansky, Theodosius. Mankind Evolving: The Evolution of the Human Species. London: Yale University Press, 1962.

Duri, Kerina, Stray-Pedersen, Babill and F. Muller. "HIV/AIDS: Zimbabwean Situation and Trends." The American Journal of Clinical Medicine Research 1/1 (2013): 15-22. https://doi.org/10.12691/ajcmr-1-1-5

Eliad, Mircea. The Sacred and the Profane: The Nature of Religion. New York: Brace and World, Inc, 1963.

Etherington, Kim. Narrative Approaches to Working with Adult Male Survivors of Childhood Sexual Abuse. London: Jessica Kingsley, 2000.

Felder, H. Cain. Troubling Biblical Waters: Race, Class and Family. New York: Orbis, 1990.

Gaylard, Rob. "Writing Black: The South African Short Story by Black Writers." PhD Thesis. University of Stellenbosch, 2008.

Goldenberg, M. David. "The Curse of Ham: A Case of Rabbinic Racism?" Pages 21-55 in Struggles in the Promised Land. Edited by Jack Salzman and Cornel West. Oxford: Oxford University Press, 1997.

Gottwald, Norman K. The Hebrew Bible. A Socio-Literary Introduction to the Old Testament. Philadelphia: Fortress, 1985.

Hayes, Daniel J. (1996). "The Cushites: A Black Nation in Ancient History." Bibliotheca Sacra 153 (Oct-Dec, 1996): 396-409.

Herschbach, R. Dennis. "Knowledge as Technology: Implications for Instruction." $\begin{array}{lllll}\text { Journal of Technology Education } & \text { 7/1 }\end{array}$ https://doi.org/10.21061/jte.v7i1.a.3

Hochschild, Jennifer L. "The Skin Colour Paradox and the American Racial Order." Social Forces 86/2 (2007): 1-28. https://doi.org/10.1093/sf/86.2.643

Hooker, Morna D. "Interchange in Christ." Journal of Theological Studies 22/2 (1971): 349-361. https://doi.org/10.1093/jts/XXII.2.349

Johnston, Melissa P. "Secondary Data Analysis: A Method of which the Time Has Come." Qualitative and Quantitative Methods in Libraries 3 (2014):619-626.

Kaplan, Steven. "The Africanisation of Missionary Christianity: History and Typology." Journal of Religion in Africa 16/3 (1986):166-186. https://doi.org/ $\underline{10.1163 / 157006686 \text { X00128 }}$

Khedr, Mohamed. "Is There Any Difference between Someone Who is Educated and Someone Learned?" Available online: https://www.bayt.com/en/specialties/q/ 69021/is-there-any-difference-between-someone-who-is-educated-and-someonelearned/. Accessed 17 December 2017.

Körtner, Ulrich. "Ecological ethics and creation faith." HTS Theological Studies 72/4 (2016): a3296. https://doi.org/10.4102/hts.v72i4.3296

Krakowski, Menachem. "Reclaiming the Self: Adam's Sin and the Human Psyche". Hakirah: Flatbush Journal of Jewish Law and Though 5(2007):151-170.

Lan, David. Guns and Rain: Guerrillas Mediums in Zimbabwe. Harare: James Currey Publishers, 1985.

Lenzi, Alan and Stökl, Jonathan, Divination, Politics \& Ancient Near Eastern Empires. Atlanta: Society for Biblical Literature, 2014.

Loubser, J.A (Bobby). "Unpacking the Expression 'Indigenous Knowledge Systems.", 
386 Rugwiji, “Conceptualising Biblical View of Curse,” 31/2 (2018): 363-388

Indilinga: African Journal of Indigenous Knowledge Systems 4/6 (2005):74-88.

Machingura, Francis and Museka, Godfrey. "Blood as the Seat of Life: The Blood Paradox among Afro-Christians.” Perichoresis 14/1 (2016):41-62. https://doi.org /10.1515/perc-2016-0003

Mapara, Jacob and Shumirai Nyota. "Suburban Blight: Perpetuating Colonial Memory through Naming in Mutare, Zimbabwe." Pages 289-306 in The Postcolonial Conditions of Names and Naming Practices in Southern Africa. Edited by Oliver Nyambi, Tendai Mangena and Charles Pfukwa. Cambridge Scholars Publishing, 2016.

Masaka, Dennis and Chingombe, Agrippa. "The Relevance of 'Gata' Among the Shona of Zimbabwe in the Context of the HIV/AIDS Pandemic." Journal of Pan African Studies 3/1 (2009): 189-199.

Mawere, Munyaradzi. "Indigenous Knowledge Systems (IKS) for Establishing a Moral, Virtuous Society: Lessons from Selected IKSs in Zimbabwe and Mozambique." Journal of Sustainable Development in Africa 12/7 (2010): 209221.

."Life after Bodily Death: Myth or Reality?" The Zambezia Journal of Humanities 32/2 (2005): 26-46.

Mbeki, Thabo. Africa - the Time Has Come. Cape Town: Tafelberg, 1998.

Mbiti, John S. Introduction to African Religion. Cape Town: Heinemann International Literature \& Textbooks, 1975.

Meiring, Jacob J.S. "Shem, Ham, Japheth and Zuma - Genesis 9:25-27 and Masculinities in South Africa." Stellenbosch Theological Journal 2/1 (2016): 223-240. https://doi.org/10.17570/stj.2016.v2n1.a11

Meredith, Martin. The Fate of Africa: From the Hopes of Freedom to the Heart of Despair-A History of Fifty Years of Independence. New York: Public Affairs, 2006.

Mills, Greg. "Why Is Africa Poor?” Development Policy Briefing Paper No. 6. Centre for Global Liberty and Prosperity. 6 December, 2010.

Monhla, Elias. "Africanisation within the URCSA: A Critical Focus on How the Church Order Relates to African Marriages.” MA Diss., University of Pretoria, 2014.

Mostamai, Dimpho. "When Elections Become a Curse: Redressing Electoral Violence in Africa." EISA Policy Brief 1 (2010):1-9.

Mutema, Gaudencia. "Phenomenology, Hermeneutics and the Study of Indigenous Knowledge." Indilinga: African Journal of Indigenous Knowledge Systems 2/1 (2003):81-88.

Muwati Itai, Gambahaya Zifilike and Mangena Fainos. "Echoing Silences as a Paradigm for Restorative Justice in Post-Conflict Zimbabwe: A Philosophical Discourse." Zambezia XXXIII i/ii (2006): 1-18.

Nantambu, Kwame. "Egypt and European Supremacy." A Current Bibliography on African Affairs 28/4 (1996/7): 357-379.

Ndlovu-Gatsheni, Sabelo J. "Making Sense of Mugabeism in Local and Global Politics: 'So Blair, Keep Your England and Let Me Keep My Zimbabwe.'” Third World Quarterly 30/6 (2009):1139-1158. https://doi.org/10.1080/01436590903037424

Ngambi, Hellicy. "Rare Leadership: An Alternative Leadership for Africa." International Journal of African Renaissance Studies 6/1 (2011): 6-23. https://doi .org/10.1080/18186874.2011.592387 
Oluwole, S. Bosede. "Oruka's Mission in African Philosophy." Pages 150-162 in Sagacious Reasoning: Henry Odera Oruka in Memoriam. Edited by H. Odera Oruka, Anke Graness and Kai Kresse. Nairobi: East African Educational Publishers, 1997.

Papyrakis, Elissaios and Reyer Gerlagh. "The Resource Curse Hypothesis and its Transmission Channels." Journal of Comparative Economics (2003): 1-13.

Reynolds, Pamela. "Children of Tribulation: The Need to Heal and the Means to Heal War Trauma." Africa 60/1 (1990): 1-38. https://doi.org/10.2307/1160425

Ross, Allen P. "The Table of Nations in Genesis 10: Its Content." Bibliotheca Sacra 138 (1980): 22-34.

Rugwiji, Temba T. "Towards the Quest for Transforming Old Testament Scholarship: The Impact of Political and Socioeconomic Crises on Scholarship in Zimbabwe." Old Testament Essays 27/3 (2014):1009-1034.

. Appropriating Judean Postexilic Literature in a Postcolonial Discourse: A Case for Zimbabwe." PhD thesis, University of South Africa, 2013.

. "Reading the Exodus Tradition from a Zimbabwean Perspective." MA Diss., University of South Africa, 2008.

Sachs, Jeffrey D. and Warner, Andrew M. "Sources of Slow Growth in African Economies." Journal of African Economies 6/3 (1996): 335-376. https://doi.org/ 10.1093/oxfordjournals.jae.a020932

Sakuhuni, C. Rose, Chidoko Clainos, Dhoro Netsai L. and Caleb Gwaindepi, "Economic Determinants of Poverty in Zimbabwe." International Journal of Economic Research 2/6 (2011):1-12.

Schmidt, Heike. "Healing Wounds of War: Memories of Violence and the Making of History in Zimbabwe's most recent past." Journal of Southern African Studies 23/2 (1997): 301-310. https://doi.org/10.1080/03057079708708538

Shizha, Edward and Kariwo, Michael, T. Education and Development in Zimbabwe: A Social, Political and Economic Analysis. Rotterdam: Sense Publishers, 2011. https://doi.org/10.1007/978-94-6091-606-9

Spangenberg, Izak. "The Job and the powerless God." Pages 304-316 in Old Testament science and reality. Edited by Willie Wessels and Eben H. Scheffler. Pretoria: Verba Vitae, 1992.

Spronk, Klaas. "Good Death and Bad Death in Ancient Israel According to Biblical Lore." Social Science and Medicine 58 (2004): 987-995. https://doi.org/10.1016 /j.socscimed.2003.10.035

Thorpe, Shirley A. African Traditional Religion. Pretoria: University of South Africa, 1991.

Unseth, Peter. "Hebrew Kush: Sudan, Ethiopia, or Where?" Africa Journal of Evangelical Theology 18/2 (1999):143-159.

Upkong, Justin S. "Rereading the Bible with African eyes." Journal of Theology for Southern Africa 91 (1995): 314.

Waldman, Nahum M. "Parents Have Eaten Sour Grapes." The Jewish Bible Quarterly 18/1 (1989): 1-5.

Wächter, Ludwig. Der Tod im Alten Testament. Stuttgart: Calwer Verlag, 1967.

Whybray, R. Norman. "Shall not the Judge of all the Earth do what is just? God's Oppression of the Innocent in the Old Testament." Pages 1-19 in Shall Not the Judge of All the Earth do what is Right? Studies on the Nature of God in Tribute 
388 Rugwiji, “Conceptualising Biblical View of Curse,” 31/2 (2018): 363-388

to James L. Crenshaw. Edited by David Penchansky and Paul L. Redditt. Winona Lake, IN: Eisenbrauns, 2000.

Temba T. Rugwiji, Department of Old Testament Studies, University of Pretoria. Email: rugwiji1964@gmail.com ORCID ID: https://orcid.org/0000-00029080-9908. 